\title{
Clinical correlates of grey matter pathology in multiple sclerosis
}

\author{
Dana Horakova ${ }^{*}$, Tomas Kalincik ${ }^{\dagger}$, Jana Blahova Dusankova and Ondrej Dolezal
}

\begin{abstract}
Traditionally, multiple sclerosis has been viewed as a disease predominantly affecting white matter. However, this view has lately been subject to numerous changes, as new evidence of anatomical and histological changes as well as of molecular targets within the grey matter has arisen. This advance was driven mainly by novel imaging techniques, however, these have not yet been implemented in routine clinical practice. The changes in the grey matter are related to physical and cognitive disability seen in individuals with multiple sclerosis. Furthermore, damage to several grey matter structures can be associated with impairment of specific functions. Therefore, we conclude that grey matter damage - global and regional - has the potential to become a marker of disease activity, complementary to the currently used magnetic resonance markers (global brain atrophy and T2 hyperintense lesions). Furthermore, it may improve the prediction of the future disease course and response to therapy in individual patients and may also become a reliable additional surrogate marker of treatment effect.
\end{abstract}

\section{Review}

Multiple sclerosis (MS) is known for the great variability of its clinical presentations, spanning the relapsingremitting course with a subsequent secondary progressive phase, primary progressive course and relapsingprogressive course. The rate of disability accumulation varies from a lack of disease activity (benign MS) to rapidly progressing (malignant) MS [1] with a range of possible neurological manifestations. Therefore, the view of MS as a heterogeneous entity resulting from a number of inter-related etiopathogenetic cascades has been receiving increasing scientific attention [2-4]. The role of the immune system is likely to be pivotal in the disease pathogenesis, however, direct causality is yet to be established [5,6]. Surrogate markers such as magnetic resonance imaging (MRI), optic coherent tomography and susceptibility genes may elucidate the great clinical variability arising from the complex etiopathogenesis. On the diagnostic level, these might help to identify the specific subtypes of disease in individual patients, predict the future MS course, and develop individually tailored therapeutic regimens $[7,8]$.

\footnotetext{
* Correspondence: dana.horakova@vfn.cz

† Contributed equally

Department of Neurology and Center of Clinical Neuroscience, Charles University in Prague, 1st Faculty of Medicine and General University Hospital, Charles University, Prague, Czech Republic
}

The currently available therapies, which are based mainly on their anti-inflammatory properties, are imperfect, with a number of patients showing only sub-optimal control over the MS activity [9]. It is therefore important that clinicians are able to predict the future response to treatment in individual patients early after disease onset in order to allow for the most appropriate treatment to be chosen [10]. Furthermore, the treatment, once administered, needs to be monitored to verify its efficacy. In both instances, surrogate markers may play significant roles $[11,12]$. Among different surrogate markers, MRI has been the only one used routinely in clinical practice. The traditional view of MS as a disease affecting predominantly white matter (WM) was driven by the higher sensitivity of the conventional MRI techniques to the WM changes [13-15]. However, these changes proved to be insufficient to explain the broad spectrum of neurological and psychological manifestations of MS satisfactorily [16-22]. Novel MRI techniques with improved sensitivity to grey matter (GM) changes [23-28] have shown that the GM damage is more prevalent than first estimated [29-34], that it may even precede development of the WM damage [35], and that it is significantly associated with physical and cognitive impairment $[11,12,31,36-47]$. The aim of this review is to summarise the current knowledge of the GM damage in MS and of its clinical implications. 


\section{Assessing grey matter pathology}

Both GM atrophy $[11,34,38,41,42,44,48]$ and GM lesions [29-32,49-52] were demonstrated in cerebral cortex and deep GM structures using MRI supported by histological studies [32,53-56]. A body of work suggested that GM atrophy occurs early in relapsing-remitting as well as primary progressive MS [15,38,57-59]. Its progression was shown to be more prominent compared to WM atrophy, which is in contrast to some of the earlier works $[12,33,34,44,60]$. GM atrophy becomes more evident with the progression of MS $[12,34,36]$ and in the chronic stages might even drive total brain atrophy [12]. Its relation to the WM changes, however, has not been sufficiently explained $[52,61,62]$. GM atrophy has been associated with several MHC II alleles [63], which are known genetic risk factors in MS [6,64]. This all implies that GM atrophy may play an important role in the pathogenesis of MS.

It is known that GM atrophy is not distributed homogeneously. Temporal and frontal cortex (including motor areas) can be affected predominantly, particularly early in the disease course [12,33,39,65-70]. The subcortical GM also shows marked atrophy, especially in the thalamus, basal ganglia (caudate and striatum) and the infratentorial structures $[58,66,71,72]$. As a result, cortico-subcortical connections might suffer significant damage [73].

According to the original pathological study of Brownell and Hughes, GM lesions comprise 26\% of all lesions identified in the central nervous system (CNS) [29]. Cortical lesions occur early in clinically isolated syndrome (CIS) and relapsing-remitting MS, as well as in primary progressive MS $(36 \%, 64 \%$ and $81 \%$ of patients, respectively) and increase in number and size with progression of the disease $[30,31,74]$. Cortical lesions are most common in the frontal and temporal cortex, predominantly affecting the motor (30-40\%) and cingulate areas (10\%) [75]. Among the subcortical GM, the structures most affected are the thalamus, basal ganglia, hypothalamus, hippocampus, cerebellum and spinal cord [76-80]. Compared to WM lesions, inflammation is less pronounced [51] and the blood-brain barrier is not disrupted in GM lesions [81]. Interestingly, T-cell mediated autoimmunity directed against contactin-2, which is present specifically within the GM, was identified as a factor contributing to the GM pathology in MS [3].

Sensitivity of the conventional MRI methods for GM lesions is low compared to WM lesions $[32,82]$. This improves with alternative techniques, such as double inversion recovery (DIR) $[25,28,83]$ and its combination with phase-sensitive inversion recovery [27], T1weighted gradient-recalled-echo [23] and higher fieldstrength MRI $[24,26]$. Another promising approach is the combination of the conventional MRI techniques with magnetisation transfer ratio [73,84]. Furthermore, diffusion tensor imaging has the potential to uncover progressive microstructural changes in normal-appearing GM [85]. Functional changes in MS can be examined using functional MRI to study re-organisation of the cortex, positron emission tomography to establish activation of microglia, or continuous arterial spin labelling to analyse brain perfusion [86-88]. Despite their promising results, the non-conventional MRI techniques have so far found only a limited use in routine clinical practice, partly due to their sparse availability and high technological and time requirements, and partly due to limited reproducibility of their outcomes [89].

\section{Clinical correlates of GM impairment}

Abnormalities of GM are present early in CIS [90-95] and evolve with its progression to definite MS [11,96-98]. Numerous works have shown that the changes in GM are closely associated with both physical disability and cognitive impairment (see Table 1) [31,33,37,68,99-101].

\section{Physical disability}

GM atrophy It is known that GM atrophy is correlated with physical disability and its progression $(\mathrm{r}=0.47$ $0.59)[12,36,39,102,103]$. According to a number of studies, this relation is stronger than that of WM matter changes $[33,57,67,99,100]$. Fisniku and co-workers showed that GM atrophy, unlike WM atrophy, increases in patients with moderate disability [Expanded Disability Status Scale (EDSS) > 3] [36]. This view is further supported by the fact that the GM atrophy rate is accelerated upon conversion from CIS to the relapsing-remitting and secondary progressive stages ( $3.4 \times$ and $14 \times$ the normal rates, respectively), while WM atrophy remains stable throughout the MS course $(3 \times$ the normal rate) $[11,12]$. The association of GM atrophy with disability becomes even stronger in primary progressive MS [33]. All this suggests that the GM changes could be more representative of the progressive damage to the CNS and the resulting physical disability than the WM damage. However, it is worth noting that also some contrasting results have been reported [15]. These opposing conclusions may relate to inequalities in studied cohorts, such as differences in disease stages or subtypes.

GM lesions Apart from the GM atrophy, cortical and subcortical inflammatory (T2 hyperintense) GM lesions also contribute to the overall disability in MS [104,105]. They show mild correlation with EDSS and moderate correlation with its changes in time [31]. Similar to the atrophy, primary progressive MS shows more pronounced accumulation of the GM lesions, parallel with accumulation of the physical disability [30]. On the 
Table 1 Selected works studying grey matter changes and their relations to physical and cognitive impairment in MS

\begin{tabular}{|c|c|c|c|c|}
\hline Study & Patients & $\begin{array}{l}\text { Follow- } \\
\text { up } \\
\text { (years) }\end{array}$ & $\begin{array}{l}\text { MRI } \\
\text { measures }\end{array}$ & Main outcomes \\
\hline $\begin{array}{l}\text { Dalton et al., } \\
2004[11]\end{array}$ & $58 \mathrm{CIS}$ & 3 & GMF & $\begin{array}{l}\text { Decrease in GMF was higher in patients who converted to CDMS }(-3.3 \%) \text { than in } \\
\text { those who did not }(-1.1 \%) \text {. }\end{array}$ \\
\hline $\begin{array}{l}\text { Fisher et al., } \\
2008 \text { [12] }\end{array}$ & $\begin{array}{l}7 \mathrm{CIS} \\
36 \\
\text { RRMS } \\
27 \mathrm{SPMS} \\
17 \mathrm{HC}\end{array}$ & 4 & $\begin{array}{l}\text { BPF, GMF, } \\
\text { WMF }\end{array}$ & $\begin{array}{l}\text { GMF decrease was more pronounced in patients compared to HC: } \\
\text { CIS converting to RRMS, 3.4x; RRMS, } 8.1 \times \text {; RRMS converting to SPMS, 12.4x; SPMS, } \\
14 \times \text {. } \\
\text { WMF decrease was } 3 \times \text { higher in all patient sub-groups than in HC. }\end{array}$ \\
\hline $\begin{array}{l}\text { Fisniku et al., } \\
2008[36]\end{array}$ & $\begin{array}{l}29 \mathrm{CIS} \\
33 \\
\text { RRMS } \\
11 \text { SPMS } \\
25 \mathrm{HC}\end{array}$ & $\begin{array}{l}\text { 20/cross- } \\
\text { sectional }\end{array}$ & $\begin{array}{l}\text { GMF, GMV } \\
\text { WMF }\end{array}$ & GMF but not WMF correlated with EDSS $(r=0.48)$ and MSFC sub-scores $(r=0.59)$. \\
\hline $\begin{array}{l}\text { Horakova et al., } \\
2009[102]\end{array}$ & $\begin{array}{l}170 \\
\text { RRMS }\end{array}$ & 5 & GMV, PBVC & Decline in PBVC and GMV were the strongest MRI predictors of disability progression. \\
\hline $\begin{array}{l}\text { Calabrese et al., } \\
2009[30]\end{array}$ & $\begin{array}{l}48 \\
\text { PPMS }\end{array}$ & 2 & $\begin{array}{l}\text { GMF, cortical lesions } \\
\text { (volume, count) }\end{array}$ & $\begin{array}{l}\text { Baseline volume of cortical lesions correlated with EDSS }(r=0.48) \text { and its change } \\
\text { over } 2 \text { years }(r=0.38) \text {. }\end{array}$ \\
\hline $\begin{array}{l}\text { Calabrese et al., } \\
2011[96]\end{array}$ & $\begin{array}{l}105 \mathrm{ClS} \\
42 \mathrm{HC}\end{array}$ & 4 & Regional atrophy & $\begin{array}{l}\text { Atrophy of the superior frontal gyrus, thalamus, and cerebellum predicted } \\
\text { independently conversion from CIS to CDMS. }\end{array}$ \\
\hline $\begin{array}{l}\text { Roosendaal et } \\
\text { al., } 2011[55]\end{array}$ & $\begin{array}{l}95 \mathrm{CIS} \\
657 \\
\text { RRMS } \\
125 \\
\text { SPMS } \\
50 \\
\text { PPMS }\end{array}$ & $\begin{array}{c}\text { cross- } \\
\text { sectional }\end{array}$ & GMV & $\begin{array}{l}\text { GMV was lower in SPMS than RRMS, and was the strongest independent predictor of } \\
\text { physical disability and cognitive impairment. }\end{array}$ \\
\hline $\begin{array}{l}\text { Amato et al., } \\
2004[40]\end{array}$ & $\begin{array}{l}41 \\
\text { RRMS } \\
16 \mathrm{HC}\end{array}$ & $\begin{array}{c}\text { cross- } \\
\text { sectional }\end{array}$ & GMV & $\begin{array}{l}\text { Cortical atrophy was found in cognitively impaired but not in cognitively preserved } \\
\text { patients, and was correlated with a poorer performance on tests of verbal memory, } \\
\text { attention, and verbal fluency. }\end{array}$ \\
\hline $\begin{array}{l}\text { Amato et al., } \\
2007[101]\end{array}$ & $\begin{array}{l}28 \mathrm{RR} \\
\mathrm{MS}\end{array}$ & 2.5 & $\begin{array}{l}\text { GMV, NCV } \\
\text { PBVC }\end{array}$ & $\begin{array}{l}\text { Decrease in cortical volume was significantly higher in cognitively deteriorating than } \\
\text { in stable or improving patients }(-43 \mathrm{ml} \text { vs. }-18 \mathrm{ml}) \text {. }\end{array}$ \\
\hline $\begin{array}{l}\text { Tekok-Kilic et } \\
\text { al., } 2007 \text { [68] }\end{array}$ & $\begin{array}{l}59 \\
\text { CDMS }\end{array}$ & $\begin{array}{c}\text { cross- } \\
\text { sectional }\end{array}$ & GMF & $\begin{array}{l}\text { Frontal atrophy was associated with impaired memory (auditory/verbal, visual } \\
\text { episodic and working). }\end{array}$ \\
\hline $\begin{array}{l}\text { Houtchens et } \\
\text { al., } 2007[161]\end{array}$ & $\begin{array}{l}62 \mathrm{RR} \\
\mathrm{MS} \\
16 \mathrm{SP} \\
\mathrm{MS} \\
1 \mathrm{PP} \mathrm{MS} \\
16 \mathrm{HC}\end{array}$ & $\begin{array}{c}\text { cross- } \\
\text { sectional }\end{array}$ & thalamic volume & $\begin{array}{l}\text { Thalamic volume was } 17 \% \text { lower in the MS group than in } \mathrm{HC} \text {, and was associated } \\
\text { with impaired cognitive performance }(r=0.51-0.72) \text { and physical disability }(r=0.32) \text {. }\end{array}$ \\
\hline $\begin{array}{l}\text { Calabrese et al., } \\
2009 \text { [37] }\end{array}$ & $\begin{array}{l}70 \mathrm{RR} \\
\mathrm{MS}\end{array}$ & $\begin{array}{c}\text { cross- } \\
\text { sectional }\end{array}$ & $\begin{array}{l}\text { cortical lesions } \\
\text { NCV }\end{array}$ & $\begin{array}{l}\text { Higher number and volume of cortical lesions and lower volume of neocortical grey } \\
\text { matter were seen in cognitively impaired vs. cognitively preserved patients. }\end{array}$ \\
\hline
\end{tabular}

BPF, brain parenchymal fraction; CDMS, clinically definite multiple sclerosis; CIS, clinically isolated syndrome; EDSS, Expanded Disability Status Scale; GMF, grey matter fraction; GMV, grey matter volume; HC, healthy controls; MS, multiple sclerosis; MSFC, Multiple Sclerosis Functional Composite; NCV, normalised cortical volume; PBVC, percentage brain volume change; RRMS, relapsing-remitting multiple sclerosis; SPMS, secondary progressive multiple sclerosis; WMF, white matter fraction

other hand, in a benign form of MS with only a modest disability after long disease duration, the GM lesions are sparse [106].

T2 hypointense lesions have also been reported in MS. They may represent iron deposits and foci of brain degeneration $[107,108]$, predominantly located within the thalamus, striatum and rolandic cortex [107-109]. Similar to the T2 hyperintense lesions, T2 hypointense lesions are associated with physical disability [43,109-111] as well as cognitive impairment [112], and are predictive of future brain atrophy $[108,113]$.
Regional GM changes Among the regional GM changes, it is in particular the cortical atrophy which is thought to be associated with physical disability $[13,15,33,100]$. However, structural changes within the thalamus could also play role in the accumulation of disability [114]. It was suggested that MS-associated fatigue could be secondary to the regional atrophy of the fronto-parietal cortex, striatum and thalamus [115-118] as well as the higher overall GM lesion burden $[69,119]$. On the other hand, impaired gait may be associated with the damage to the dentate nucleus [43]. Another 
co-morbidity of MS - restless legs syndrome - is probably related to the changes in the cervical spinal cord [120], where demyelination of GM is more extensive than that of WM [77]. Apart from the routinely evaluated signs of the physical disability, the GM lesions are likely to contribute to the increased epileptic activity [121] which occurs in $2.9 \%$ of patients with MS (i.e. its prevalence is $3-6 \times$ higher compared to healthy population) [122-124]. Yet, it is not known whether the severity of physical impairment is proportional to the GM lesion volume or if it depends more on the topography of the focal GM damage.

GM reorganisation Besides the limited regenerative capacity of the CNS [125], adaptation of neural networks represents important compensatory mechanism of the damaged CNS. Cortical reorganisation, as shown by a number of studies with functional MRI, occurs early in MS, but its extent varies greatly among patients. It can be visualised as a non-normal cortical activation pattern, elicited by standardised motor and cognitive tasks [126-133]. For instance, during motor processing, recruitment of higher (supplementary) areas may be seen even with simple movements in MS patients but not in healthy subjects $[129,130,134]$. Similar functional reorganisation takes place in the cervical spinal cord [135]. This can be interpreted as compensation for damage inflicted by the demyelination and neuronal loss. It is possible that more extensive (or efficient) compensation and axonal regeneration contribute to a less severe course of MS and slower accumulation of the CNS structural damage [106,134].

Evaluation of disability Research of functional outcomes of the structural changes in MS depends on the ability of clinicians to quantify physical and cognitive impairment in MS patients. Two scales, EDSS and Multiple Sclerosis Functional Composite (MSFC), have been used most commonly to evaluate the physical impairment in clinical practice and in research. Both of these scales quantify the extent of disability only imperfectly [136]. For EDSS, this is attributed to suboptimal inter-rater reproducibility, lack of weighted functional sub-scores and omission of psychological assessment [137], while for MSFC, this is due to practice effects, variations in reference populations, omission of visual assessment and lack of accepted definition of a clinically meaningful change [138]. EDSS mainly evaluates the physical component of the impairment, with the emphasis on ambulation, assessing the cognitive impairment only marginally. On the other hand, MSFC is a more complex scale with objective evaluation of ambulation (timed 25-foot walk test), fine motor skills (9-hole peg test) and cognition (3-second Paced Auditory Serial Addition Test). It was suggested that MSFC may better correlate with GM atrophy than EDSS [12,36]. Furthermore, it is possible that EDSS is more sensitive to disability progression in patients with mild physical disability, while being less sensitive to the progression in patients with more severe disability [139]. This raises concerns about the value of EDSS in secondary progressive MS. In any case, instruments assessing the physical disability reliably at all stages and in all courses of MS are critical for accurate evaluation of the descriptive and prognostic value of the GM changes.

\section{Cognitive impairment}

Cognitive impairment is highly prevalent in MS, affecting $40-65 \%$ of patients with all disease courses and in all its clinical stages [140]. Although the character and severity of the cognitive impairment vary widely among the patients, information processing speed, attention, recent and long-term memory, executive functions and visuospatial abilities seem to be the most affected domains, whereas general intelligence, language and certain aspects of memory (short-term capacity and implicit memory) are spared, and overt dementia is rare in MS [141-143]. In addition, in patients with disease onset before the age of 18, impairment of expressive language and visuomotor integration were described [144]. This suggests that even in young patients the damage to the CNS may exceed its plasticity. Overall, the extreme variability of the cognitive impairment may depend on several factors, such as patient age, gender, age at disease onset, level of education and cognitive reserve $[145,146]$.

GM vs. WM changes Even though significant correlations between the amount and the regions of the WM atrophy vs. the degree and pattern of cognitive impairment were shown [147], studies failed to explain the full array of cognitive impairment by the WM damage only [148]. A range of specific cognitive deficits, such as memory impairment, low information processing speed and attention deficits, could be better explained by the cortical GM lesions rather than the subcortical WM lesions [148]. Changes in the GM might therefore add to our understanding of the causality of the cognitive impairment in MS. For example, more widespread atrophy and hypometabolism of GM can be found in the cognitively impaired patients than in those cognitively intact $[149,150]$. Moreover, it is of interest that the cognitive impairment is more prominent at the time of conversion from the relapsing-remitting to the secondary progressive course $[151,152]$, which is also marked by accelerated degeneration of the cerebral GM [12]. In fact, a number of works provided evidence of a strong association between GM impairment (lesions and atrophy) and global or selective cognitive disability in MS $[40,68,101,142,149,153]$, which may imply a causative relation [148]. 
Regional GM changes A pattern of widespread cortical thinning was found in cognitively impaired patients with relapsing-remitting MS [149,154]. Even a cortical variant of MS was described in those with the cognitive impairment among the initial manifestations of MS $[155,156]$. It was shown that neocortical atrophy is related to the impairment of verbal memory $[40,65,68,153]$, visual episodic and working memory [68], verbal fluency [40,101], attention/concentration [40] and processing speed $[65,70,157]$. It may also be responsible for subtle personality changes observed in MS patients, such as disinhibition and euphoria $[153,158]$. More specifically, atrophy of the prefrontal, precentral and superior parietal cortex is related to the decreased processing speed and impaired calculation abilities [70]. Left frontal atrophy occurs in patients with impaired auditory/verbal memory, while right frontal atrophy is related to impaired visual episodic and working memory [68]. Atrophy of the mesial temporal cortex is associated with decreased processing speed and impaired episodic and verbal memory $[159,160]$. Atrophy of the subcortical GM structures can be evaluated either directly or indirectly - using enlargement of the third ventricle as a marker $[68,154]$. Of the subcortical GM, the most relevant are the atrophy, structural changes and altered metabolism of the thalamus, which are linked with deterioration in multiple cognitive domains $[114,144,150,154,157,161,162]$.

Compared to GM atrophy, there is considerably less evidence to support contribution of demyelinating lesions of GM to cognitive impairment. The volume of the cortical lesions shows only a modest association with cognitive impairment, while an increase in the lesion volume seems to be moderately associated with cognitive deterioration $[31,37,163,164]$. More specifically, lesions in the medial frontal and temporal cortex seem to correlate with impaired memory [164].

Overall, it can be speculated that the cognitive decline observed in MS patients results from focal inflammatory lesions and widespread GM loss. Despite the fact that the neuropsychological profiles of MS patients cannot be defined as either purely "cortical" or "subcortical" [165], it is likely that it is the impairment of the cortical GM which determines the level and character of cognitive dysfunction.

\section{GM as a surrogate marker}

Objective indicators of MS activity as well as predictors of future disease course and treatment efficacy applicable in individual patients are crucial for making appropriate therapeutic decisions in routine clinical practice. A number of works have addressed these issues, and several markers, both clinical and paraclinical, have been suggested [7,21,166-169]. Yet, accuracy of the MRI markers, particularly when used in individual patients, is only limited [16,170,171].

\section{Marker of MS activity}

According to the existing evidence, changes in GM might represent a reliable marker of disease activity and of CNS damage. The relatively less pronounced inflammation within GM is likely to result in lesser fluctuations of its changes triggered by the relapsing inflammatory activity [51]. Moreover, focal oedema and treatment-associated pseudoatrophy, which may mask the changes reflecting the activity of MS, are known to be less evident in GM $[172,173]$. Therefore GM lesions and atrophy, rather than WM changes, might better reflect long-term changes which drive the accumulation of disability [174].

In fact, assessment of GM lesions improves the specificity and accuracy of MRI diagnostic criteria [175]. At the same time, GM atrophy correlates closely with the progression of CIS to clinically definite MS $[11,12,39,176]$. Furthermore, both GM lesions and GM atrophy can be used to predict this conversion $[96,175]$. Long-term accumulation of disability is also predicted by the diffuse changes in the GM [36,177]. It can be speculated that an even better prognostic value may be achieved with assessment of regional GM atrophy.

\section{Monitoring of treatment efficacy}

For the reasons discussed above, the impairment of GM has the potential to become an important marker of the efficacy of immunomodulatory remedies [21]. On the other hand, the less inflammatory nature of GM damage $[51,178,179]$ and better preservation of the blood-brain barrier within altered GM [180] may diminish the response of GM to immunomodulatory therapy. Calabrese and co-workers demonstrated a decrease in accumulation of GM lesions and cortical atrophy in patients treated with disease modifying drugs, and reported a more pronounced effect of subcutaneous interferon $\beta$ compared to intramuscular interferon $\beta$ and glatiramer acetate [181]. Zivadinov and co-authors observed ameliorated progression of GM atrophy in patients treated with interferon $\beta$ [182]. In contrast, Benfeldt and coworkers reported more pronounced atrophy in the fronto-temporal, cingulate and cerebellar cortex in patients treated with interferon $\beta$. It is therefore apparent that more work evaluating the effect of immunomodulation on the changes in GM is required.

\section{Conclusions}

The growing body of evidence supports the view of MS as a disease not only of WM but also of GM. The mechanisms responsible for the inter-individual variation in the extent of GM and WM pathology are largely unknown, and their identification will significantly contribute to the understanding of the MS etiopathogenesis. 
On the diagnostic level, GM atrophy and lesions provide information complementary to the conventional MRI variables and further improve correlation between the radiological and clinical variables $[118,183]$. Thus, GM pathology may not only serve as a new marker for the existing immunomodulatory therapies but may also provide a potential target for novel therapies.

\section{Abbreviations}

CIS: clinically isolated syndrome; CNS: central nervous system; EDSS: Expanded Disability Status Scale; GM: grey matter; MRI: magnetic resonance imaging; MS: multiple sclerosis; MSFC: Multiple Sclerosis Functional Composite; WM: white matter

\section{Authors' contributions}

$\mathrm{DH}$ prepared the Introduction and Physical disability sections and Table 1, and reviewed the manuscript. TK prepared the Physical disability section and Table 1, and edited and reviewed the manuscript. JBD prepared the Cognitive impairment section and reviewed the manuscript. OD prepared the Assessing grey matter pathology section and reviewed the manuscript. All authors read and approved the final manuscript.

\section{Competing interests}

Dana Horakova has received speaker honoraria and consultant fees from Biogen Idec, Merck-Serono, Bayer Shering and Teva, as well as support for research activities from Biogen Idec.

Tomas Kalincik has received compensation for travel and honoraria from Biogen Idec, Sanofi Aventis, Teva and Merck-Serono.

Jana Blahova Dusankova has received speaker honoraria and compensation for travel from Biogen Idec, Bayer Shering, Merck-Serono and Novartis. Ondrej Dolezal has received speaker honoraria and compensation for travel from Biogen Idec, Merck-Serono and Novartis.

The authors have received financial support from the Czech Ministry of Health [MSM 0021620849].

Received: 17 September 2011 Accepted: 7 March 2012 Published: 7 March 2012

\section{References}

1. Weiner $\mathrm{HL}$ : The challenge of multiple sclerosis: how do we cure a chronic heterogeneous disease? Ann Neurol 2009, 65(3):239-248.

2. Compston A, Coles A: Multiple sclerosis. Lancet 2008, 372(9648):1502-1517.

3. Derfuss T, Parikh K, Velhin S, Braun M, Mathey E, Krumbholz M, Kumpfel T, Moldenhauer A, Rader C, Sonderegger P, et al: Contactin-2/TAG-1-directed autoimmunity is identified in multiple sclerosis patients and mediates gray matter pathology in animals. Proc Natl Acad Sci USA 2009, 106(20):8302-8307.

4. Lassmann $\mathrm{H}$, van Horssen J: The molecular basis of neurodegeneration in multiple sclerosis. FEBS letters 2011

5. Frischer JM, Bramow S, Dal-Bianco A, Lucchinetti CF, Rauschka H, Schmidbauer M, Laursen H, Sorensen PS, Lassmann H: The relation between inflammation and neurodegeneration in multiple sclerosis brains. Brain 2009, 132(Pt 5):1175-1189.

6. IMSGC: Genetic risk and a primary role for cell-mediated immune mechanisms in multiple sclerosis. Nature 2011, 476(7359):214-219.

7. Rio J, Comabella M, Montalban X: Predicting responders to therapies for multiple sclerosis. Nat Rev Neurol 2009, 5(10):553-560.

8. Sormani MP, Bonzano L, Roccatagliata L, De Stefano N: Magnetic resonance imaging as surrogate for clinical endpoints in multiple sclerosis: data on novel oral drugs. Mult Scler 2011, 17(5):630-633.

9. Havrdova E, Galetta S, Stefoski D, Comi G: Freedom from disease activity in multiple sclerosis. Neurology 2010, 74(Suppl 3):S3-7.

10. Hartung HP, Montalban X, Sorensen PS, Vermersch P, Olsson T: Principles of a new treatment algorithm in multiple sclerosis. Expert Rev Neurother 2011, 11(3):351-362.
11. Dalton CM, Chard DT, Davies GR, Miszkiel KA, Altmann DR, Fernando K, Plant GT, Thompson AJ, Miller DH: Early development of multiple sclerosis is associated with progressive grey matter atrophy in patients presenting with clinically isolated syndromes. Brain 2004, 127(Pt 5):1101-1107.

12. Fisher E, Lee JC, Nakamura K, Rudick RA: Gray matter atrophy in multiple sclerosis: a longitudinal study. Ann Neurol 2008, 64(3):255-265.

13. Chard DT, Griffin CM, Parker GJ, Kapoor R, Thompson AJ, Miller DH: Brain atrophy in clinically early relapsing-remitting multiple sclerosis. Brain 2002, 125(Pt 2):327-337.

14. Ge Y, Grossman Rl, Udupa JK, Babb JS, Nyul LG, Kolson DL: Brain atrophy in relapsing-remitting multiple sclerosis: fractional volumetric analysis of gray matter and white matter. Radiology 2001, 220(3):606-610.

15. Sastre-Garriga J, Ingle GT, Chard DT, Ramio-Torrenta L, Miller DH, Thompson AJ: Grey and white matter atrophy in early clinical stages of primary progressive multiple sclerosis. Neuroimage 2004, 22(1):353-359.

16. Barkhof F: The clinico-radiological paradox in multiple sclerosis revisited. Curr Opin Neurol 2002, 15(3):239-245.

17. Comi G, Filippi M, Martinelli V, Sirabian G, Visciani A, Campi A, Mammi S, Rovaris $\mathrm{M}$, Canal N: Brain magnetic resonance imaging correlates of cognitive impairment in multiple sclerosis. J Neurol Sci 1993, 115(Suppl): 566-73.

18. Thorpe JW, Kidd D, Moseley IF, Kenndall BE, Thompson AJ, MacManus DG McDonald WI, Miller DH: Serial gadolinium-enhanced MRI of the brain and spinal cord in early relapsing-remitting multiple sclerosis. Neurology 1996, 46(2):373-378.

19. Simon JH, Jacobs LD, Campion MK, Rudick RA, Cookfair DL, Herndon RM, Richert JR, Salazar AM, Fischer JS, Goodkin DE, et al: A longitudinal study of brain atrophy in relapsing multiple sclerosis. The Multiple Sclerosis Collaborative Research Group (MSCRG). Neurology 1999, 53(1):139-148.

20. Fox NC, Jenkins R, Leary SM, Stevenson VL, Losseff NA, Crum WR, Harvey RJ, Rossor MN, Miller DH, Thompson AJ: Progressive cerebral atrophy in MS: a serial study using registered, volumetric MRI. Neurology 2000, 54(4):807-812.

21. Zivadinov R, Stosic M, Cox JL, Ramasamy DP, Dwyer MG: The place of conventional MRI and newly emerging MRI techniques in monitoring different aspects of treatment outcome. J Neurol 2008, 255(Suppl 1):61-74.

22. Rudick RA, Fisher E, Lee JC, Simon J, Jacobs L: Use of the brain parenchymal fraction to measure whole brain atrophy in relapsingremitting MS. Multiple Sclerosis Collaborative Research Group. Neurology 1999, 53(8):1698-1704.

23. Bagnato F, Butman JA, Gupta S, Calabrese M, Pezawas L, Ohayon JM, TovarMoll F, Riva M, Cao MM, Talagala SL, et al: In vivo detection of cortical plaques by MR imaging in patients with multiple sclerosis. AJNR Am J Neuroradiol 2006, 27(10):2161-2167.

24. Geurts JJ, Blezer EL, Vrenken H, van der Toorn A, Castelijns JA, Polman CH, Pouwels PJ, Bo L, Barkhof F: Does high-field MR imaging improve cortical lesion detection in multiple sclerosis? J Neurol 2008, 255(2):183-191.

25. Geurts JJ, Pouwels PJ, Uitdehaag BM, Polman CH, Barkhof F, Castelijns JA: Intracortical lesions in multiple sclerosis: improved detection with 3D double inversion-recovery MR imaging. Radiology 2005, 236(1):254-260

26. Kangarlu A, Bourekas EC, Ray-Chaudhury A, Rammohan KW: Cerebral cortical lesions in multiple sclerosis detected by MR imaging at 8 Tesla. AJNR Am J Neuroradiol 2007, 28(2):262-266.

27. Nelson F, Poonawalla AH, Hou P, Huang F, Wolinsky JS, Narayana PA: Improved identification of intracortical lesions in multiple sclerosis with phase-sensitive inversion recovery in combination with fast double inversion recovery MR imaging. AJNR Am J Neuroradiol 2007, 28(9):1645-1649.

28. Pouwels PJ, Kuijer JP, Mugler JP, Guttmann CR, Barkhof F: Human gray matter: feasibility of single-slab 3D double inversion-recovery highspatial-resolution MR imaging. Radiology 2006, 241(3):873-879.

29. Brownell B, Hughes JT: The distribution of plaques in the cerebrum in multiple sclerosis. J Neurol Neurosurg Psychiatry 1962, 25:315-320.

30. Calabrese M, Rocca MA, Atzori M, Mattisi I, Bernardi V, Favaretto A, Barachino L, Romualdi C, Rinaldi L, Perini P, et al: Cortical lesions in primary progressive multiple sclerosis: a 2-year longitudinal MR study. Neurology 2009, 72(15):1330-1336. 
31. Calabrese M, Rocca MA, Atzori M, Mattisi I, Favaretto A, Perini P, Gallo P, Filippi M: A 3-year magnetic resonance imaging study of cortical lesions in relapse-onset multiple sclerosis. Ann Neurol 2010, 67(3):376-383.

32. Geurts JJ, Bo L, Pouwels PJ, Castelijns JA, Polman CH, Barkhof F: Cortical lesions in multiple sclerosis: combined postmortem MR imaging and histopathology. AJNR Am J Neuroradiol 2005, 26(3):572-577.

33. De Stefano N, Matthews PM, Filippi M, Agosta F, De Luca M, Bartolozzi ML, Guidi L, Ghezzi A, Montanari E, Cifelli A, et al: Evidence of early cortical atrophy in MS: relevance to white matter changes and disability. Neurology 2003, 60(7):1157-1162.

34. Horakova D, Cox JL, Havrdova E, Hussein S, Dolezal O, Cookfair D, Dwyer MG, Seidl Z, Bergsland N, Vaneckova M, et al: Evolution of different MRI measures in patients with active relapsing-remitting multiple sclerosis over 2 and 5 years: a case-control study. J Neurol Neurosurg Psychiatry 2008, 79(4):407-414.

35. Pirko I, Lucchinetti CF, Sriram S, Bakshi R: Gray matter involvement in multiple sclerosis. Neurology 2007, 68(9):634-642.

36. Fisniku LK, Chard DT, Jackson JS, Anderson VM, Altmann DR, Miszkiel KA Thompson AJ, Miller DH: Gray matter atrophy is related to long-term disability in multiple sclerosis. Ann Neurol 2008, 64(3):247-254.

37. Calabrese M, Agosta F, Rinaldi F, Mattisi I, Grossi P, Favaretto A, Atzori M, Bernardi V, Barachino L, Rinaldi L, et al: Cortical lesions and atrophy associated with cognitive impairment in relapsing-remitting multiple sclerosis. Arch Neurol 2009, 66(9):1144-1150.

38. Chard DT, Griffin CM, Rashid W, Davies GR, Altmann DR, Kapoor R, Barker GJ, Thompson AJ, Miller DH: Progressive grey matter atrophy in clinically early relapsing-remitting multiple sclerosis. Mult Scler 2004 10(4):387-391.

39. Chen JT, Narayanan S, Collins DL, Smith SM, Matthews PM, Arnold DL: Relating neocortical pathology to disability progression in multiple sclerosis using MRI. Neuroimage 2004, 23(3):1168-1175.

40. Amato MP, Bartolozzi ML, Zipoli V, Portaccio E, Mortilla M, Guidi L, Siracusa G, Sorbi S, Federico A, De Stefano N: Neocortical volume decrease in relapsing-remitting MS patients with mild cognitive impairment. Neurology 2004, 63(1):89-93.

41. Sastre-Garriga J, Ingle GT, Chard DT, Cercignani M, Ramio-Torrenta L, Miller DH, Thompson AJ: Grey and white matter volume changes in early primary progressive multiple sclerosis: a longitudinal study. Brain 2005, 128(Pt 6):1454-1460.

42. Valsasina P, Benedetti B, Rovaris M, Sormani MP, Comi G, Filippi M: Evidence for progressive gray matter loss in patients with relapsingremitting MS. Neurology 2005, 65(7):1126-1128.

43. Tjoa CW, Benedict RH, Weinstock-Guttman B, Fabiano AJ, Bakshi R: MRI T2 hypointensity of the dentate nucleus is related to ambulatory impairment in multiple sclerosis. J Neuro/ Sci 2005, 234(1-2):17-24.

44. Tiberio M, Chard DT, Altmann DR, Davies G, Griffin CM, Rashid W, SastreGarriga J, Thompson AJ, Miller DH: Gray and white matter volume changes in early RRMS: a 2-year longitudinal study. Neurology 2005, 64(6):1001-1007.

45. Smith SM, Zhang Y, Jenkinson M, Chen J, Matthews PM, Federico A, De Stefano N: Accurate, robust, and automated longitudinal and crosssectional brain change analysis. Neuroimage 2002, 17(1):479-489.

46. Zivadinov R, Grop A, Sharma J, Bratina A, Tjoa CW, Dwyer M, Zorzon M: Reproducibility and accuracy of quantitative magnetic resonance imaging techniques of whole-brain atrophy measurement in multiple sclerosis. J Neuroimaging 2005, 15(1):27-36.

47. Simon $J H$, Schiffer RB, Rudick RA, Herndon RM: Quantitative determination of MS-induced corpus callosum atrophy in vivo using MR imaging. AJNR Am J Neuroradiol 1987, 8(4):599-604.

48. Tedeschi G, Lavorgna L, Russo P, Prinster A, Dinacci D, Savettieri G, Quattrone A, Livrea P, Messina C, Reggio A, et al: Brain atrophy and lesion load in a large population of patients with multiple sclerosis. Neurology 2005, 65(2):280-285.

49. Kidd D, Barkhof F, McConnell R, Algra PR, Allen IV, Revesz T: Cortical lesions in multiple sclerosis. Brain 1999, 122(Pt 1):17-26.

50. Kutzelnigg A, Lassmann H: Cortical lesions and brain atrophy in MS. J Neurol Sci 2005, 233(1-2):55-59.

51. Peterson JW, Bo L, Mork S, Chang A, Trapp BD: Transected neurites, apoptotic neurons, and reduced inflammation in cortical multiple sclerosis lesions. Ann Neurol 2001, 50(3):389-400.
52. Wegner C, Esiri MM, Chance SA, Palace J, Matthews PM: Neocortical neuronal, synaptic, and glial loss in multiple sclerosis. Neurology 2006 67(6):960-967

53. Chard D, Miller D: Grey matter pathology in clinically early multiple sclerosis: evidence from magnetic resonance imaging. J Neurol Sci 2009, 282(1-2):5-11.

54. Wylezinska M, Cifelli A, Jezzard P, Palace J, Alecci M, Matthews PM: Thalamic neurodegeneration in relapsing-remitting multiple sclerosis. Neurology 2003, 60(12):1949-1954.

55. Roosendaal SD, Bendfeldt K, Vrenken H, Polman CH, Borgwardt S, Radue EW, Kappos L, Pelletier D, Hauser SL, Matthews PM, et al: Grey matter volume in a large cohort of MS patients: relation to MRI parameters and disability. Mult Scler 2011, 17(9):1098-1106.

56. Sormani M, Stromillo ML, Battaglini M, Signori A, De Stefano N: Modelling the distribution of cortical lesions in multiple sclerosis. Mult Scler 2011.

57. Khaleeli Z, Cercignani M, Audoin B, Ciccarelli O, Miller DH, Thompson AJ: Localized grey matter damage in early primary progressive multiple sclerosis contributes to disability. Neuroimage 2007, 37(1):253-261.

58. Sepulcre J, Sastre-Garriga J, Cercignani M, Ingle GT, Miller DH, Thompson AJ: Regional gray matter atrophy in early primary progressive multiple sclerosis: a voxel-based morphometry study. Arch Neurol 2006, 63(8):1175-1180.

59. Audoin B, Davies G, Rashid W, Fisniku L, Thompson AJ, Miller DH: Voxelbased analysis of grey matter magnetization transfer ratio maps in early relapsing remitting multiple sclerosis. Mult Scler 2007, 13(4):483-489.

60. Quarantelli M, Ciarmiello A, Morra VB, Orefice G, Larobina M, Lanzillo R, Schiavone V, Salvatore E, Alfano B, Brunetti A: Brain tissue volume changes in relapsing-remitting multiple sclerosis: correlation with lesion load. Neuroimage 2003, 18(2):360-366.

61. Pomeroy IM, Jordan EK, Frank JA, Matthews PM, Esiri MM: Diffuse cortical atrophy in a marmoset model of multiple sclerosis. Neurosci Lett 2008, 437(2):121-124.

62. Geurts JJ, Stys PK, Minagar A, Amor S, Zivadinov R: Gray matter pathology in (chronic) MS: modern views on an early observation. J Neurol Sci 2009, 282(1-2):12-20.

63. Zivadinov R, Uxa L, Bratina A, Bosco A, Srinivasaraghavan B, Minagar A, Ukmar M, Benedetto S, Zorzon M: HLA-DRB1*1501, -DQB1*0301, $-\mathrm{DQB} 1{ }^{*} 0302$, $-\mathrm{DQB} 1{ }^{*} 0602$, and $-\mathrm{DQB} 1{ }^{*} 0603$ alleles are associated with more severe disease outcome on MRI in patients with multiple sclerosis. International review of neurobiology 2007, 79:521-535.

64. Zivadinov R, Uxa L, Zacchi T, Nasuelli D, Ukmar M, Furlan C, Pozzi-Mucelli R, Tommasi MA, Locatelli L, Ulivi S, et al: HLA genotypes and disease severity assessed by magnetic resonance imaging findings in patients with multiple sclerosis. J Neurol 2003, 250(9):1099-1106.

65. Benedict RH, Zivadinov R, Carone DA, Weinstock-Guttman B, Gaines J, Maggiore C, Sharma J, Tomassi MA, Bakshi R: Regional lobar atrophy predicts memory impairment in multiple sclerosis. AJNR Am J Neuroradiol 2005, 26(7):1824-1831.

66. Prinster A, Quarantelli M, Orefice G, Lanzillo R, Brunetti A, Mollica C, Salvatore E, Morra VB, Coppola G, Vacca G, et al: Grey matter loss in relapsing-remitting multiple sclerosis: a voxel-based morphometry study. Neuroimage 2006, 29(3):859-867.

67. Sailer M, Fischl B, Salat D, Tempelmann C, Schonfeld MA, Busa E, Bodammer $\mathrm{N}$, Heinze $\mathrm{HJ}$, Dale A: Focal thinning of the cerebral cortex in multiple sclerosis. Brain 2003, 126(Pt 8):1734-1744.

68. Tekok-Kilic A, Benedict RH, Weinstock-Guttman B, Dwyer MG, Carone D, Srinivasaraghavan B, Yella V, Abdelrahman N, Munschauer F, Bakshi R, et al: Independent contributions of cortical gray matter atrophy and ventricle enlargement for predicting neuropsychological impairment in multiple sclerosis. Neuroimage 2007, 36(4):1294-1300.

69. Riccitelli G, Rocca MA, Forn C, Colombo B, Comi G, Filippi M: Voxelwise assessment of the regional distribution of damage in the brains of patients with multiple sclerosis and fatigue. AJNR Am J Neuroradiol 2011, 32(5):874-879.

70. Morgen K, Sammer G, Courtney SM, Wolters T, Melchior H, Blecker CR, Oschmann P, Kaps M, Vaitl D: Evidence for a direct association between cortical atrophy and cognitive impairment in relapsing-remitting MS. Neuroimage 2006, 30(3):891-898.

71. Bermel RA, Innus MD, Tjoa CW, Bakshi R: Selective caudate atrophy in multiple sclerosis: a 3D MRI parcellation study. Neuroreport 2003, 14(3):335-339. 
72. Cifelli A, Arridge M, Jezzard P, Esiri MM, Palace J, Matthews PM: Thalamic neurodegeneration in multiple sclerosis. Ann Neurol 2002, 52(5):650-653.

73. Ciccarelli O, Werring DJ, Wheeler-Kingshott CA, Barker GJ, Parker GJ, Thompson AJ, Miller DH: Investigation of MS normal-appearing brain using diffusion tensor MRI with clinical correlations. Neurology 2001, 56(7):926-933.

74. Calabrese M, De Stefano N, Atzori M, Bernardi V, Mattisi I, Barachino L, Morra A, Rinaldi L, Romualdi C, Perini P, et al: Detection of cortical inflammatory lesions by double inversion recovery magnetic resonance imaging in patients with multiple sclerosis. Arch Neurol 2007, 64(10):1416-1422.

75. Calabrese M, Battaglini M, Giorgio A, Atzori M, Bernardi V, Mattisi I, Gallo P, De Stefano N: Imaging distribution and frequency of cortical lesions in patients with multiple sclerosis. Neurology 2010, 75(14):1234-1240.

76. Geurts JJ, Bo L, Roosendaal SD, Hazes T, Daniels R, Barkhof F, Witter MP, Huitinga I, van der Valk P: Extensive hippocampal demyelination in multiple sclerosis. J Neuropathol Exp Neurol 2007, 66(9):819-827.

77. Gilmore CP, Bo L, Owens T, Lowe J, Esiri MM, Evangelou N: Spinal cord gray matter demyelination in multiple sclerosis-a novel pattern of residual plaque morphology. Brain Pathol 2006, 16(3):202-208.

78. Huitinga I, De Groot CJ, Van der Valk P, Kamphorst W, Tilders FJ, Swaab DF: Hypothalamic lesions in multiple sclerosis. J Neuropathol Exp Neurol 2001, 60(12):1208-1218.

79. Vercellino M, Plano F, Votta B, Mutani R, Giordana MT, Cavalla P: Grey matter pathology in multiple sclerosis. J Neuropathol Exp Neurol 2005, 64(12):1101-1107.

80. Calabrese M, Mattisi I, Rinaldi F, Favaretto A, Atzori M, Bernardi V, Barachino $L$, Romualdi $C$, Rinaldi $L$, Perini $P$, et al: Magnetic resonance evidence of cerebellar cortical pathology in multiple sclerosis. J Neurol Neurosurg Psychiatry 2010, 81(4):401-404

81. van Horssen J, Brink BP, de Vries HE, van der Valk P, Bo L: The blood-brain barrier in cortical multiple sclerosis lesions. J Neuropathol Exp Neurol 2007, 66(4):321-328.

82. Dolezal O, Dwyer MG, Horakova D, Havrdova E, Minagar A, Balachandran S, Bergsland N, Seidl Z, Vaneckova M, Fritz D, et al: Detection of cortical lesions is dependent on choice of slice thickness in patients with multiple sclerosis. International review of neurobiology 2007, 79:475-489.

83. Rinaldi F, Calabrese M, Grossi P, Puthenparampil M, Perini P, Gallo P: Cortical lesions and cognitive impairment in multiple sclerosis. Neurol Sci 2010, 31(Suppl 2):S235-237.

84. Davies GR, Altmann DR, Hadjiprocopis A, Rashid W, Chard DT, Griffin CM, Tofts PS, Barker GJ, Kapoor R, Thompson AJ, et al: Increasing normalappearing grey and white matter magnetisation transfer ratio abnormality in early relapsing-remitting multiple sclerosis. J Neurol 2005, 252(9):1037-1044.

85. Oreja-Guevara C, Rovaris M, lannucci G, Valsasina P, Caputo D, Cavarretta R, Sormani MP, Ferrante P, Comi G, Filippi M: Progressive gray matter damage in patients with relapsing-remitting multiple sclerosis: a longitudinal diffusion tensor magnetic resonance imaging study. Arch Neurol 2005, 62(4):578-584.

86. Versijpt J, Debruyne JC, Van Laere KJ, De Vos F, Keppens J, Strijckmans K, Achten E, Slegers G, Dierckx RA, Korf J, et al: Microglial imaging with positron emission tomography and atrophy measurements with magnetic resonance imaging in multiple sclerosis: a correlative study. Mult Scler 2005, 11(2):127-134.

87. Rashid W, Parkes LM, Ingle GT, Chard DT, Toosy AT, Altmann DR, Symms MR, Tofts PS, Thompson AJ, Miller DH: Abnormalities of cerebral perfusion in multiple sclerosis. J Neurol Neurosurg Psychiatry 2004, 75(9):1288-1293.

88. Rocca MA, Pagani E, Ghezzi A, Falini A, Zaffaroni M, Colombo B, Scotti G, Comi G, Filippi M: Functional cortical changes in patients with multiple sclerosis and nonspecific findings on conventional magnetic resonance imaging scans of the brain. Neuroimage 2003, 19(3):826-836.

89. Geurts JJ, Roosendaal SD, Calabrese M, Ciccarelli O, Agosta F, Chard DT, Gass A, Huerga E, Moraal B, Pareto D, et al: Consensus recommendations for MS cortical lesion scoring using double inversion recovery MRI. Neurology 2011, 76(5):418-424.

90. Audoin B, Zaaraoui W, Reuter F, Rico A, Malikova I, Confort-Gouny S, Cozzone PJ, Pelletier J, Ranjeva JP: Atrophy mainly affects the limbic system and the deep grey matter at the first stage of multiple sclerosis. J Neurol Neurosurg Psychiatry 2010, 81(6):690-695.
91. Calabrese M, Atzori M, Bernardi V, Morra A, Romualdi C, Rinaldi L, McAuliffe MJ, Barachino L, Perini P, Fischl B, et al: Cortical atrophy is relevant in multiple sclerosis at clinical onset. J Neurol 2007, 254(9):1212-1220.

92. Fisniku LK, Altmann DR, Cercignani M, Tozer DJ, Chard DT, Jackson JS, Miszkiel KA, Schmierer K, Thompson AJ, Miller DH: Magnetization transfer ratio abnormalities reflect clinically relevant grey matter damage in multiple sclerosis. Mult Scler 2009, 15(6):668-677.

93. Henry RG, Shieh M, Amirbekian B, Chung S, Okuda DT, Pelletier D: Connecting white matter injury and thalamic atrophy in clinically isolated syndromes. J Neurol Sci 2009, 282(1-2):61-66.

94. Henry RG, Shieh M, Okuda DT, Evangelista A, Gorno-Tempini ML, Pelletier D: Regional grey matter atrophy in clinically isolated syndromes at presentation. J Neurol Neurosurg Psychiatry 2008, 79(11):1236-1244.

95. Roosendaal SD, Bendfeldt K, Vrenken H, Polman CH, Borgwardt S, Radue EW, Kappos L, Pelletier D, Hauser SL, Matthews PM, et al: Grey matter volume in a large cohort of MS patients: relation to MRI parameters and disability. Mult Scler 2011.

96. Calabrese M, Rinaldi F, Mattisi I, Bernardi V, Favaretto A, Perini P, Gallo P: The predictive value of gray matter atrophy in clinically isolated syndromes. Neurology 2011, 77(3):257-263.

97. Raz E, Cercignani M, Sbardella E, Totaro P, Pozzilli C, Bozzali M, Pantano P: Gray- and white-matter changes 1 year after first clinical episode of multiple sclerosis: MR imaging. Radiology 2010, 257(2):448-454.

98. Rocca MA, Agosta F, Sormani MP, Fernando K, Tintore M, Korteweg T, Tortorella P, Miller DH, Thompson A, Rovira A, et al: A three-year, multiparametric MRI study in patients at presentation with CIS. J Neurol 2008, 255(5):683-691.

99. Bakshi R, Benedict RH, Bermel RA, Jacobs L: Regional brain atrophy is associated with physical disability in multiple sclerosis: semiquantitative magnetic resonance imaging and relationship to clinical findings. $J$ Neuroimaging 2001, 11(2):129-136.

100. Sanfilipo MP, Benedict RH, Sharma J, Weinstock-Guttman B, Bakshi R: The relationship between whole brain volume and disability in multiple sclerosis: a comparison of normalized gray vs. white matter with misclassification correction. Neuroimage 2005, 26(4):1068-1077.

101. Amato MP, Portaccio E, Goretti B, Zipoli V, Battaglini M, Bartolozzi ML, Stromillo ML, Guidi L, Siracusa G, Sorbi S, et al: Association of neocortical volume changes with cognitive deterioration in relapsing-remitting multiple sclerosis. Arch Neurol 2007, 64(8):1157-1161.

102. Horakova D, Dwyer MG, Havrdova E, Cox JL, Dolezal O, Bergsland N Rimes B, Seidl Z, Vaneckova M, Zivadinov R: Gray matter atrophy and disability progression in patients with early relapsing-remitting multiple sclerosis: a 5-year longitudinal study. J Neurol Sci 2009, 282(1-2):112-119.

103. Bonati U, Fisniku LK, Altmann DR, Yiannakas MC, Furby J, Thompson AJ, Miller DH, Chard DT: Cervical cord and brain grey matter atrophy independently associate with long-term MS disability. J Neurol Neurosurg Psychiatry 2011, 82(4):471-472.

104. Hayton T, Furby J, Smith KJ, Altmann DR, Brenner R, Chataway J, Hughes RA, Hunter K, Tozer DJ, Miller DH, et al: Grey matter magnetization transfer ratio independently correlates with neurological deficit in secondary progressive multiple sclerosis. J Neurol 2009, 256(3):427-435.

105. Rovaris M, Judica E, Sastre-Garriga J, Rovira A, Sormani MP, Benedetti B, Korteweg T, De Stefano N, Khaleeli Z, Montalban X, et al: Large-scale, multicentre, quantitative MRI study of brain and cord damage in primary progressive multiple sclerosis. Mult Scler 2008, 14(4):455-464

106. Calabrese M, Filippi M, Rovaris M, Bernardi V, Atzori M, Mattisi I, Favaretto A, Grossi P, Barachino L, Rinaldi L, et al: Evidence for relative cortical sparing in benign multiple sclerosis: a longitudinal magnetic resonance imaging study. Mult Scler 2009, 15(1):36-41.

107. Drayer B, Burger P, Hurwitz B, Dawson D, Cain J: Reduced signal intensity on MR images of thalamus and putamen in multiple sclerosis: increased iron content? AJR American journal of roentgenology 1987, 149(2):357-363.

108. Bakshi R, Dmochowski J, Shaikh ZA, Jacobs L: Gray matter T2 hypointensity is related to plaques and atrophy in the brains of multiple sclerosis patients. J Neurol Sci 2001, 185(1):19-26.

109. Bakshi R, Shaikh ZA, Janardhan V: MRI T2 shortening ('black T2') in multiple sclerosis: frequency, location, and clinical correlation. Neuroreport 2000, 11(1):15-21.

110. Neema M, Stankiewicz J, Arora A, Dandamudi VS, Batt CE, Guss ZD, AlSabbagh A, Bakshi R: T1- and T2-based MRI measures of diffuse gray 
matter and white matter damage in patients with multiple sclerosis. $J$ Neuroimaging 2007, 17(Suppl 1):16S-21S.

111. Neema M, Arora A, Healy BC, Guss ZD, Brass SD, Duan Y, Buckle GJ, Glanz Bl, Stazzone L, Khoury SJ, et al: Deep gray matter involvement on brain MRI scans is associated with clinical progression in multiple sclerosis. J Neuroimaging 2009, 19(1):3-8.

112. Brass SD, Benedict RH, Weinstock-Guttman B, Munschauer F, Bakshi R: Cognitive impairment is associated with subcortical magnetic resonance imaging grey matter T2 hypointensity in multiple sclerosis. Mult Scler 2006, 12(4):437-444.

113. Bermel RA, Puli SR, Rudick RA, Weinstock-Guttman B, Fisher E, Munschauer FE, Bakshi R: Prediction of longitudinal brain atrophy in multiple sclerosis by gray matter magnetic resonance imaging $\mathrm{T} 2$ hypointensity. Arch Neurol 2005, 62(9):1371-1376.

114. Tovar-Moll F, Evangelou IE, Chiu AW, Richert ND, Ostuni JL, Ohayon JM, Auh S, Ehrmantraut M, Talagala SL, McFarland HF, et al: Thalamic involvement and its impact on clinical disability in patients with multiple sclerosis: a diffusion tensor imaging study at 3T. AJNR Am J Neuroradiol 2009, 30(7):1380-1386.

115. Niepel G, Tench Ch R, Morgan PS, Evangelou N, Auer DP Constantinescu CS: Deep gray matter and fatigue in MS: a T1 relaxation time study. J Neurol 2006, 253(7):896-902.

116. Filippi M, Rocca MA, Colombo B, Falini A, Codella M, Scotti G, Comi G: Functional magnetic resonance imaging correlates of fatigue in multiple sclerosis. Neuroimage 2002, 15(3):559-567.

117. Calabrese M, Rinaldi F, Grossi P, Mattisi I, Bernardi V, Favaretto A, Perini P, Gallo P: Basal ganglia and frontal/parietal cortical atrophy is associated with fatigue in relapsing-remitting multiple sclerosis. Mult Scler 2010, 16(10):1220-1228.

118. Poonawalla AH, Datta S, Juneja V, Nelson F, Wolinsky JS, Cutter G, Narayana PA: Composite MRI scores improve correlation with EDSS in multiple sclerosis. Mult Scler 2010, 16(9):1117-1125.

119. Sepulcre J, Masdeu JC, Goni J, Arrondo G, Velez de Mendizabal N, Bejarano B, Villoslada P: Fatigue in multiple sclerosis is associated with the disruption of frontal and parietal pathways. Mult Scler 2009, 15(3):337-344.

120. Manconi M, Rocca MA, Ferini-Strambi L, Tortorella P, Agosta F, Comi G, Filippi M: Restless legs syndrome is a common finding in multiple sclerosis and correlates with cervical cord damage. Mult Scler 2008, 14(1):86-93.

121. Calabrese M, De Stefano N, Atzori M, Bernardi V, Mattisi I, Barachino L, Rinaldi L, Morra A, McAuliffe MM, Perini P, et al: Extensive cortical inflammation is associated with epilepsy in multiple sclerosis. J Neurol 2008, 255(4):581-586.

122. Poser CM, Brinar W: Epilepsy and multiple sclerosis. Epilepsy Behav 2003, 4(1):6-12.

123. Moreau T, Sochurkova D, Lemesle M, Madinier G, Billiar T, Giroud M, Dumas R: Epilepsy in patients with multiple sclerosis: radiological-clinical correlations. Epilepsia 1998, 39(8):893-896.

124. Sokic DV, Stojsavljevic N, Drulovic J, Dujmovic I, Mesaros S, Ercegovac M, Peric V, Dragutinovic G, Levic Z: Seizures in multiple sclerosis. Epilepsia 2001, 42(1):72-79.

125. Meier DS, Weiner HL, Guttmann CR: Time-series modeling of multiple sclerosis disease activity: a promising window on disease progression and repair potential? Neurotherapeutics: the journal of the American Society for Experimental NeuroTherapeutics 2007, 4(3):485-498.

126. Filippi M, Rocca MA, Falini A, Caputo D, Ghezzi A, Colombo B, Scotti G, Comi G: Correlations between structural CNS damage and functional MRI changes in primary progressive MS. Neuroimage 2002, 15(3):537-546.

127. Lee M, Reddy H, Johansen-Berg H, Pendlebury S, Jenkinson M, Smith S, Palace J, Matthews PM: The motor cortex shows adaptive functional changes to brain injury from multiple sclerosis. Ann Neurol 2000, 47(5):606-613.

128. Reddy H, Narayanan S, Arnoutelis R, Jenkinson M, Antel J, Matthews PM, Arnold DL: Evidence for adaptive functional changes in the cerebral cortex with axonal injury from multiple sclerosis. Brain 2000, 123(Pt 11):2314-2320

129. Valsasina P, Rocca MA, Absinta M, Sormani MP, Mancini L, De Stefano N Rovira A, Gass A, Enzinger C, Barkhof F, et al: A multicentre study of motor functional connectivity changes in patients with multiple sclerosis. Eur J Neurosci 2011, 33(7):1256-1263.
130. Rico A, Zaaraoui W, Franques J, Attarian S, Reuter F, Malikova I, ConfortGouny S, Soulier E, Pouget J, Cozzone PJ, et al: Motor cortical reorganization is present after a single attack of multiple sclerosis devoid of cortico-spinal dysfunction. MAGMA 2011, 24(2):77-84.

131. Cader S, Cifelli A, Abu-Omar Y, Palace J, Matthews PM: Reduced brain functional reserve and altered functional connectivity in patients with multiple sclerosis. Brain 2006, 129(Pt 2):527-537.

132. Parry AM, Scott RB, Palace J, Smith S, Matthews PM: Potentially adaptive functional changes in cognitive processing for patients with multiple sclerosis and their acute modulation by rivastigmine. Brain 2003, 126(Pt 12):2750-2760.

133. Audoin B, Ibarrola D, Ranjeva JP, Confort-Gouny S, Malikova I, Ali-Cherif A, Pelletier J, Cozzone P: Compensatory cortical activation observed by fMRI during a cognitive task at the earliest stage of MS. Hum Brain Mapp 2003, 20(2):51-58.

134. Giorgio A, Portaccio E, Stromillo ML, Marino S, Zipoli V, Battaglini M, Blandino A, Bartolozzi ML, Siracusa G, Amato MP, et al: Cortical functional reorganization and its relationship with brain structural damage in patients with benign multiple sclerosis. Mult Scler 2010, 16(11):1326-1334.

135. Agosta F, Valsasina P, Rocca MA, Caputo D, Sala S, Judica E, Stroman PW, Filippi M: Evidence for enhanced functional activity of cervical cord in relapsing multiple sclerosis. Magn Reson Med 2008, 59(5):1035-1042.

136. Goldman MD, Motl RW, Rudick RA: Possible clinical outcome measures for clinical trials in patients with multiple sclerosis. Ther Adv Neurol Disord 2010, 3(4):229-239.

137. Hobart J, Freeman J, Thompson A: Kurtzke scales revisited: the application of psychometric methods to clinical intuition. Brain 2000, 123(Pt 5):1027-1040.

138. Polman CH, Rudick RA: The multiple sclerosis functional composite: a clinically meaningful measure of disability. Neurology 2010, 74(Suppl 3): S8-15.

139. Rudick RA, Lee JC, Nakamura K, Fisher E: Gray matter atrophy correlates with MS disability progression measured with MSFC but not EDSS. J Neurol Sci 2009, 282(1-2):106-111.

140. Patti F: Cognitive impairment in multiple sclerosis. Mult Scler 2009, 15(1):2-8.

141. Rao SM: Neuropsychology of multiple sclerosis. Curr Opin Neurol 1995, 8(3):216-220.

142. Tur C, Penny S, Khaleeli Z, Altmann D, Cipolotti L, Ron M, Thompson A, Ciccarelli O: Grey matter damage and overall cognitive impairment in primary progressive multiple sclerosis. Mult Scler 2011.

143. Chiaravalloti ND, DeLuca J: Cognitive impairment in multiple sclerosis. Lancet Neurol 2008, 7(12):1139-1151.

144. Till C, Ghassemi R, Aubert-Broche B, Kerbrat A, Collins DL, Narayanan S, Arnold DL, Desrocher M, Sled JG, Banwell BL: MRI correlates of cognitive impairment in childhood-onset multiple sclerosis. Neuropsychology 2011 25(3):319-332.

145. Amato MP, Goretti B, Ghezzi A, Lori S, Zipoli V, Moiola L, Falautano M, De Caro MF, Viterbo R, Patti F, et al: Cognitive and psychosocial features in childhood and juvenile MS: two-year follow-up. Neurology 2010, 75(13):1134-1140.

146. Benedict RH, Zivadinov R: Risk factors for and management of cognitive dysfunction in multiple sclerosis. Nat Rev Neurol 2011, 7(6):332-342.

147. Amato MP, Zipoli V, Portaccio E: Multiple sclerosis-related cognitive changes: a review of cross-sectional and longitudinal studies. J Neurol SCi 2006, 245(1-2):41-46.

148. Calabrese M, Rinaldi F, Grossi P, Gallo P: Cortical pathology and cognitive impairment in multiple sclerosis. Expert Rev Neurother 2011, 11(3):425-432.

149. Calabrese M, Rinaldi F, Mattisi I, Grossi P, Favaretto A, Atzori M, Bernardi V, Barachino L, Romualdi C, Rinaldi $L$, et al: Widespread cortical thinning characterizes patients with MS with mild cognitive impairment. Neurology 2010, 74(4):321-328.

150. Blinkenberg M, Rune K, Jensen CV, Ravnborg M, Kyllingsbaek S, Holm S, Paulson OB, Sorensen PS: Cortical cerebral metabolism correlates with MRI lesion load and cognitive dysfunction in MS. Neurology 2000, 54(3):558-564.

151. Filippi M, Alberoni M, Martinelli V, Sirabian G, Bressi S, Canal N, Comi G: Influence of clinical variables on neuropsychological performance in multiple sclerosis. Eur Neurol 1994, 34(6):324-328. 
152. Benedict RH, Carone DA, Bakshi R: Correlating brain atrophy with cognitive dysfunction, mood disturbances, and personality disorder in multiple sclerosis. J Neuroimaging 2004, 14(3 Suppl):36S-45S.

153. Sanfilipo MP, Benedict RH, Weinstock-Guttman B, Bakshi R: Gray and white matter brain atrophy and neuropsychological impairment in multiple sclerosis. Neurology 2006, 66(5):685-692.

154. Benedict RH, Bruce JM, Dwyer MG, Abdelrahman N, Hussein S, WeinstockGuttman B, Garg N, Munschauer F, Zivadinov R: Neocortical atrophy, third ventricular width, and cognitive dysfunction in multiple sclerosis. Arch Neurol 2006, 63(9):1301-1306.

155. Zarei M: Clinical characteristics of cortical multiple sclerosis. J Neurol Sci 2006, 245(1-2):53-58

156. Zarei M, Chandran S, Compston A, Hodges J: Cognitive presentation of multiple sclerosis: evidence for a cortical variant. J Neurol Neurosurg Psychiatry 2003, 74(7):872-877.

157. Batista S, Zivadinov R, Hoogs M, Bergsland N, Heininen-Brown M, Dwyer MG, Weinstock-Guttman B, Benedict RH: Basal ganglia, thalamus and neocortical atrophy predicting slowed cognitive processing in multiple sclerosis. J Neurol 2011.

158. Benedict RH, Hussein S, Englert J, Dwyer MG, Abdelrahman N, Cox JL, Munschauer FE, Weinstock-Guttman B, Zivadinov R: Cortical atrophy and personality in multiple sclerosis. Neuropsychology 2008, 22(4):432-441.

159. Benedict RH, Ramasamy D, Munschauer F, Weinstock-Guttman B, Zivadinov R: Memory impairment in multiple sclerosis: correlation with deep grey matter and mesial temporal atrophy. J Neurol Neurosurg Psychiatry 2009, 80(2):201-206.

160. Anderson VM, Fisniku LK, Khaleeli Z, Summers MM, Penny SA, Altmann DR, Thompson AJ, Ron MA, Miller DH: Hippocampal atrophy in relapsingremitting and primary progressive MS: a comparative study. Mult Scler 2010, 16(9):1083-1090.

161. Houtchens MK, Benedict RH, Killiany R, Sharma J, Jaisani Z, Singh B, Weinstock-Guttman B, Guttmann CR, Bakshi R: Thalamic atrophy and cognition in multiple sclerosis. Neurology 2007, 69(12):1213-1223.

162. Hildebrandt $H$, Hahn HK, Kraus JA, Schulte-Herbruggen A, Schwarze B, Schwendemann G: Memory performance in multiple sclerosis patients correlates with central brain atrophy. Mult Scler 2006, 12(4):428-436.

163. Roosendaal SD, Moraal B, Pouwels PJ, Vrenken H, Castelijns JA, Barkhof F, Geurts JJ: Accumulation of cortical lesions in MS: relation with cognitive impairment. Mult Scler 2009, 15(6):708-714.

164. Bagnato F, Salman Z, Kane R, Auh S, Cantor FK, Ehrmantraut M, Gallo A, Ikonomidou VN, Ohayon J, Pellicano C, et al: T1 cortical hypointensities and their association with cognitive disability in multiple sclerosis. Mult Scler 2010, 16(10):1203-1212.

165. Calabrese P, Penner IK: Cognitive dysfunctions in multiple sclerosis-a "multiple disconnection syndrome"? J Neurol 2007, 254(Suppl 2):Il18-21.

166. Barkhof F, Calabresi PA, Miller DH, Reingold SC: Imaging outcomes for neuroprotection and repair in multiple sclerosis trials. Nat Rev Neurol 2009, 5(5):256-266

167. Tintore M, Rovira A, Rio J, Nos C, Grive E, Tellez N, Pelayo R, Comabella M, Sastre-Garriga J, Montalban X: Baseline MRI predicts future attacks and disability in clinically isolated syndromes. Neurology 2006, 67(6):968-972.

168. Daumer M, Neuhaus A, Herbert J, Ebers G: Prognosis of the individual course of disease: the elements of time, heterogeneity and precision. $J$ Neurol Sci 2009, 287(Suppl 1):S50-55.

169. Rio J, Castillo J, Rovira A, Tintore M, Sastre-Garriga J, Horga A, Nos C, Comabella M, Aymerich X, Montalban X: Measures in the first year of therapy predict the response to interferon beta in MS. Mult Scler 2009, 15(7):848-853.

170. Li DK, Held U, Petkau J, Daumer M, Barkhof F, Fazekas F, Frank JA, Kappos L, Miller DH, Simon JH, et al: MRI T2 lesion burden in multiple sclerosis: a plateauing relationship with clinical disability. Neurology 2006, 66(9):1384-1389.

171. Zivadinov R, Leist TP: Clinical-magnetic resonance imaging correlations in multiple sclerosis. J Neuroimaging 2005, 15(4 Suppl):10S-21S.

172. Zivadinov R, Reder AT, Filippi M, Minagar A, Stuve O, Lassmann $H$, Racke MK, Dwyer MG, Frohman EM, Khan O: Mechanisms of action of disease-modifying agents and brain volume changes in multiple sclerosis. Neurology 2008, 71(2):136-144

173. Kelemen A, Dwyer MG, Horakova D, Vaneckova M, Havrdova E, Zivadinov R: Measurement of gray matter volume is less susceptible to pseudoatrophy effect than that of white matter or whole brain volume in patients with multiple sclerosis. Results from Avonex-SteroidsAzathioprine combination study. Mult Scler 2008, 14(280):S11.

174. Rovaris M, Gallo A, Valsasina P, Benedetti B, Caputo D, Ghezzi A, Montanari E, Sormani MP, Bertolotto A, Mancardi G, et al: Short-term accrual of gray matter pathology in patients with progressive multiple sclerosis: an in vivo study using diffusion tensor MRI. Neuroimage 2005, 24(4):1139-1146.

175. Filippi M, Rocca MA, Calabrese M, Sormani MP, Rinaldi F, Perini P, Comi G, Gallo P: Intracortical lesions: relevance for new MRI diagnostic criteria for multiple sclerosis. Neurology 2010, 75(22):1988-1994.

176. Brex PA, Jenkins R, Fox NC, Crum WR, O'Riordan Jl, Plant GT, Miller DH: Detection of ventricular enlargement in patients at the earliest clinical stage of MS. Neurology 2000, 54(8):1689-1691.

177. Agosta F, Rovaris M, Pagani E, Sormani MP, Comi G, Filippi M: Magnetization transfer MRI metrics predict the accumulation of disability 8 years later in patients with multiple sclerosis. Brain 2006, 129(Pt 10):2620-2627.

178. Bo L, Vedeler CA, Nyland H, Trapp BD, Mork SJ: Intracortical multiple sclerosis lesions are not associated with increased lymphocyte infiltration. Mult Scler 2003, 9(4):323-331.

179. Brink BP, Veerhuis $R$, Breij EC, van der Valk P, Dijkstra CD, Bo L: The pathology of multiple sclerosis is location-dependent: no significant complement activation is detected in purely cortical lesions. $J$ Neuropathol Exp Neurol 2005, 64(2):147-155.

180. Geurts JJ, Barkhof F: Grey matter pathology in multiple sclerosis. Lancet Neurol 2008, 7(9):841-851.

181. Calabrese M, Bernardi V, Atzori M, Mattisi I, Favaretto A, Rinaldi F, Perini P, Gallo P: Effect of disease-modifying drugs on cortical lesions and atrophy in relapsing-remitting multiple sclerosis. Mult Scler 2011.

182. Zivadinov R, Locatelli L, Cookfair D, Srinivasaraghavan B, Bertolotto A, Ukmar M, Bratina A, Maggiore C, Bosco A, Grop A, et al: Interferon beta-1a slows progression of brain atrophy in relapsing-remitting multiple sclerosis predominantly by reducing gray matter atrophy. Mult Scler 2007, 13(4):490-501.

183. Tur C, Khaleeli Z, Ciccarelli O, Altmann DR, Cercignani M, Miller DH, Thompson AJ: Complementary roles of grey matter MTR and T2 lesions in predicting progression in early PPMS. J Neurol Neurosurg Psychiatry 2011, 82(4):423-428

\section{Pre-publication history}

The pre-publication history for this paper can be accessed here: http://www.biomedcentral.com/1471-2377/12/10/prepub

doi:10.1186/1471-2377-12-10

Cite this article as: Horakova et al:: Clinical correlates of grey matter pathology in multiple sclerosis. BMC Neurology 2012 12:10.

\section{Submit your next manuscript to BioMed Central and take full advantage of:}

- Convenient online submission

- Thorough peer review

- No space constraints or color figure charges

- Immediate publication on acceptance

- Inclusion in PubMed, CAS, Scopus and Google Scholar

- Research which is freely available for redistribution

Submit your manuscript at www.biomedcentral.com/submit
C Biomed Central 